\title{
Development of Application-Based Sepak Takraw Teaching Model and E-Learning in the Faculty of Sports Sciences Medan State University
}

\author{
Ibrahim ${ }^{1, *}$ Zulpikar Ilham ${ }^{2,}$ Usman Nasution ${ }^{3 .}$ \\ ${ }^{1,2,3}$ Departement of Physical Education Healt and Recreation of Faculty Of Sport ScienceUniversitas Negeri Medan, \\ Jl. Willem Iskandar Pasar V Medan Estate 1 ,2,3 \\ *Corresponding author. Email: Ibrahim@unimed.ac.id
}

\begin{abstract}
This study aims to improve the competence of takraw learning lectures and assist in the field of sports science, especially in the sport of sepak takraw. The media developed in the form of learning applications that are used as teaching materials in online and face-to-face learning.The learning application contains lecture materials in each face-to-face amount in the form of lecture descriptions, video variations of learning, quizzes, and other instructions that support the online learning process. This idea emerged when researchers felt the need to solve problems in the form of student difficulties in mastering learning competencies and as an alternative to learning even though they were not face to face and practiced directly during the ongoing corona virus pandemic. The research method used is a quantitative approach and uses the Research \& Development (R \& D) method from Sugiono by developing products, testing the effectiveness of products that achieve the desired goals. Outcomes and achievements in this research include conducting reputable international journals indexed by Skopus or Web of Science (Submit/Accepted/Published), appropriate technology, textbooks and speakers at international scientific meetings.
\end{abstract}

Keywords: Sepak takraw, Teaching model, E-Learning.

\section{INTRODUCTION}

Sepaktakraw is a game with a somewhat high intricacy of development, so to be skilled at playing, it is necessary to have engine abilities that help the abilities of playing sepaktakraw. needed to support the skills of playing sepak takraw include: coordination, agility, flexibility, speed, power, strength, and endurance. [1].

The purpose of this research is expected to contribute to the learning process and sports science at Medan State University.

- Develop android-based application media and video tutorials

- As a source / learning material that can be used for the continuation of future lectures and in the era of the corona virus pandemic

- Alternative learning processes that can be applied by lecturers who support courses
- Contribution of research ideas in the fields of education and sports within the Faculty of Sports Science and in the world of sports

The Covid-19 virus pandemic experienced by all people in the world affects almost all aspects of life, not least the education aspect. Instructors and educators should teach and give material through different organization based learning applications. The hardest test for instructors who educate practicum is the trouble teachers to screen the improvement of understudies skills and knowledge in practicing teaching simulations, match simulations and match management in learning the game of sepak takraw. The application created is a learning application that contains material in every face-to-face time containing lecture material, explanation videos, learning variations videos, quizzes and questions and creates an android-based sepak takraw match scorer application which is supported by video tutorials containing the use of the application., forms of match rules and how to play sepak takraw. 
Many benefits acquired of innovation use as mixed media, since sight and sound innovation can resolve the ability mastering troubles. The motivation behind sight and sound use is to settling space constraint, time, and distance in the preparation interaction. Sight and sound as learning asset can be part friend from the exploration cycle. This examination, the scientist has printed book and VCD mixed media intelligent as learning asset. The benefit of VCD mixed media intelligent decision as learning asset, to comprehend the speed of learning every competitor, can be tolerance coach since it is a program, bundle in the structure Video Reduced Circle (VCD) and a book. That can be utilized by love seat when competitor preparing autonomously as learning asset anyplace, give a target appraisal since it given extra assessment as test.

One of the objectives of the takraw theory and practice course is that students have knowledge and skills in basic sepaktakraw techniques. What is meant by basic technique is an element in the game of sepak takraw itself. These basic technical skills are needed in dealing with actual matches, without mastering the basic techniques properly and correctly, the game of sepak takraw will not take place perfectly. [2].

Sepaktakraw players must have good soccer skills to perform defensive and attacking techniques in the game of sepak takraw. Because soccer is also one of the most dominant movements in the game of sepak takraw. Silat football can be defined as a way to play the ball effectively and efficiently to get optimal results. A sepak takraw player who lacks the basic technical skills of Silat has a direct influence on the failure to quell an attack or to build an attack (smash), because soccer in the game of sepak takraw has a three uses, namely: to control, pass, and to build attacks (Smash). [3].

The method utilized in this review utilizes improvement research. Research in this learning model uses a quantitative methodology and utilizations the Research \& Development (R \& D) development model from Sugiono. The results of the application-based learning media developed are still in the initial validation stage with material experts, where the criteria discussed with material experts are designing lecture materials that are in accordance with the stages of motion, and the design of learning variation models that are designed in such a way can be done independently, individually, or in groups. The conclusion of this research is. In takraw learning lectures, where one of the skills of this talk is that understudies should have the option to turn into teachers or coaches in providing material and must be able to make or manage sepak takraw matches.

\section{METHOD}

The method utilized in this review utilizes improvement research. Research in this learning model uses a quantitative methodology and utilizations the Research \& Development (R \& D) development model from Sugiono. The research population was all PJKR students of physical education and Recreational Health Semester IV. The sample of the study was PJKR FIK Unimed students who took the sepak takraw course.

The data collection used in this study is by using a test. The test that will be used is a test of the basic technical ability of the sepak takraw game.

\section{RESULT AND DISCUSSION}

In this study, the data analysis used is to test the effectiveness of the learning application media that has been designed. The data analysis used is the t-test. The results of data analysis can be seen in the table below:

Table 1. Takraw Sepak Sila Learning T Test

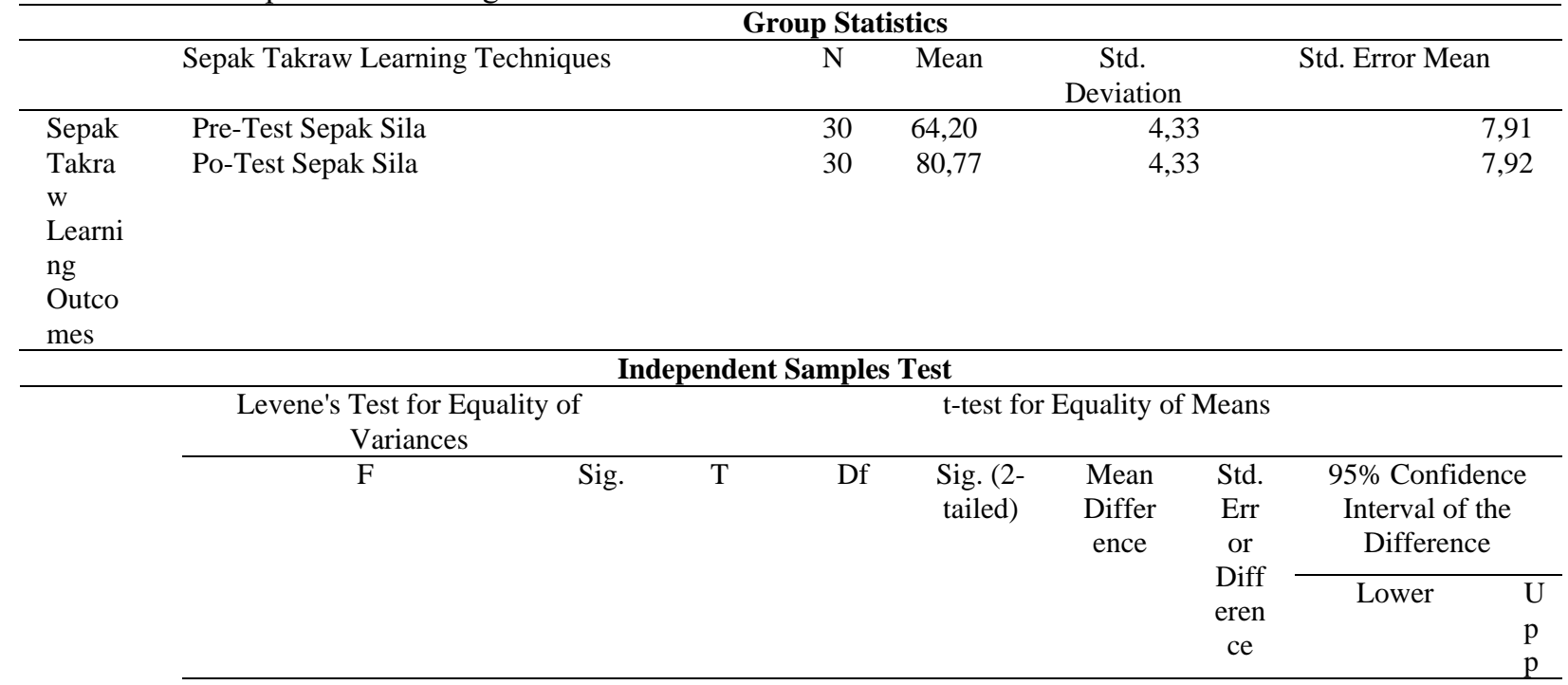




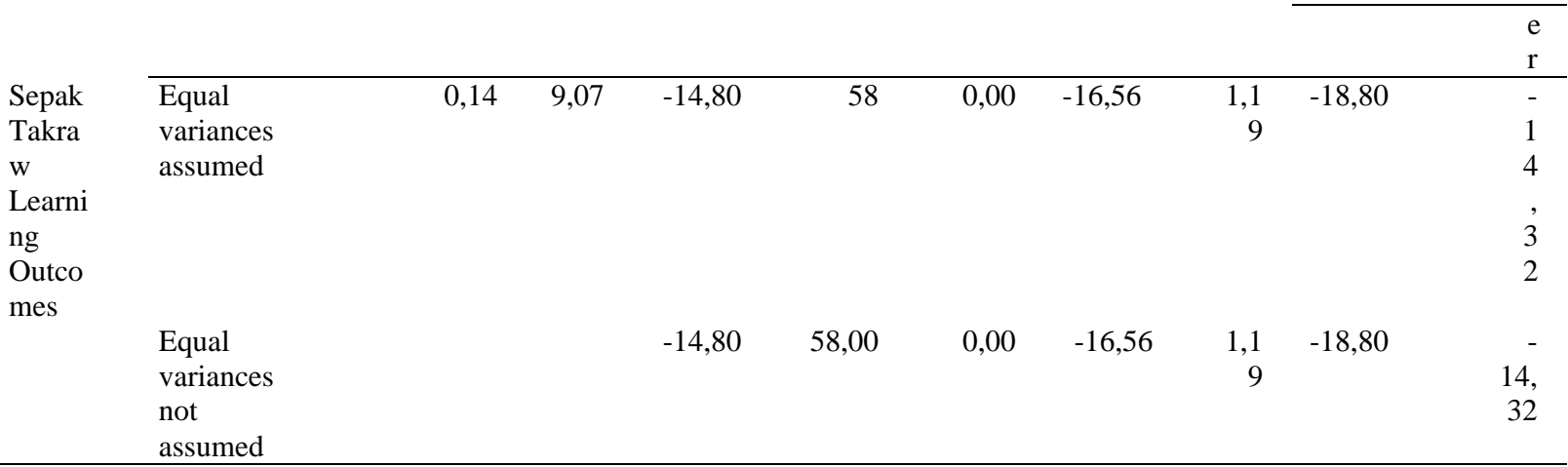

Based on the table above, it can be concluded that the results of the pre-test and the post-test in learning the basic techniques of the game of takraw have a significant value. Due to the value of Sig.(2-tailed) of $0.000<0.05$, then there is a significant difference between the scores on the pre-test and the po-test. Therefore, the results of the pre-test and po-test scores in learning the basic techniques of the takraw game are stated to have significant differences, these results can be seen in the Independent Samples Test table

Table 2. Takraw heading learning T Test

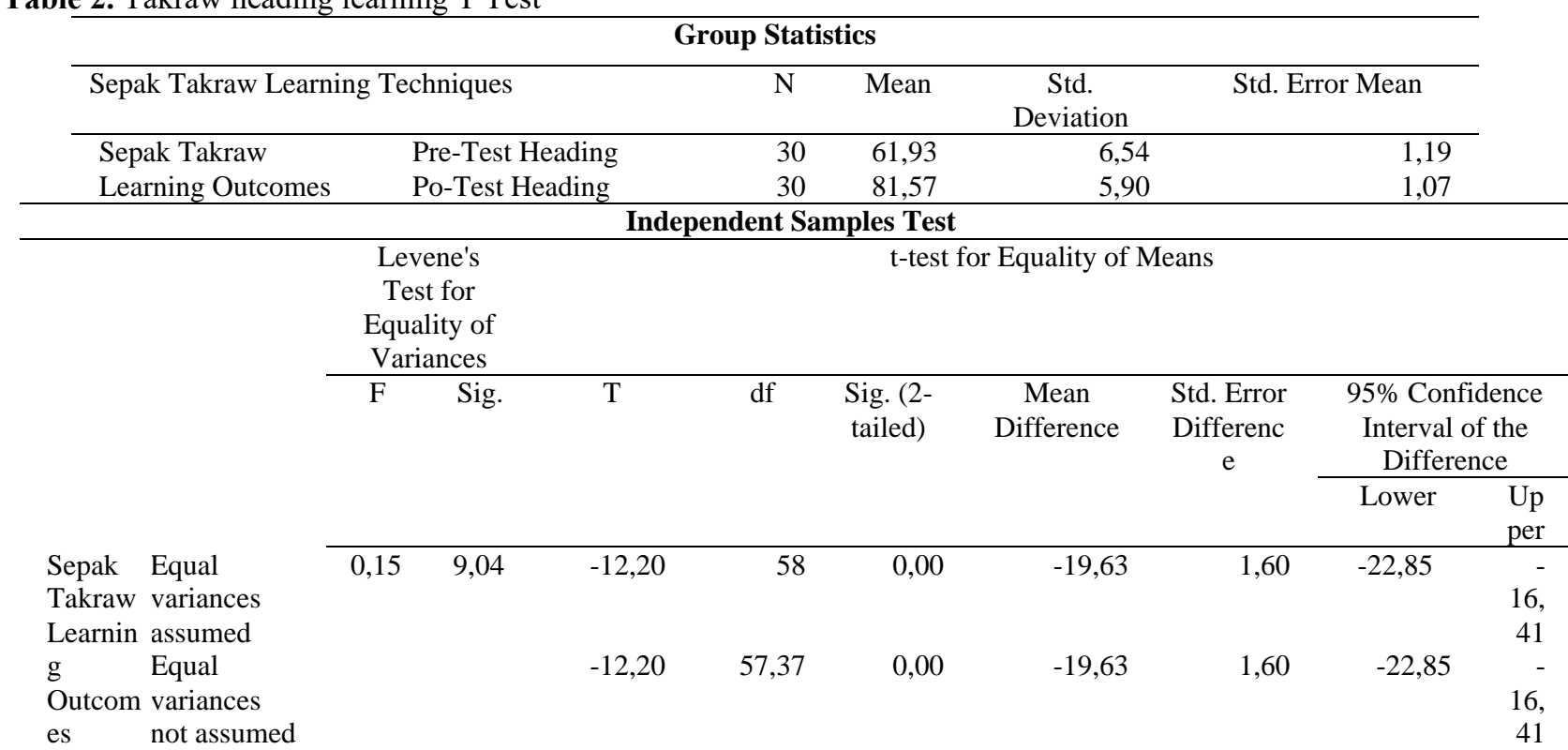

Based on the table above, it can be concluded that the results of the pre-test and the post-test in learning the heading of the game of takraw have a significant value. Due to the value of Sig.(2-tailed) of $0.000<0.05$, then there is a significant difference between the scores on the pre-test and the po-test. Therefore, the results of the pretest and po-test scores in learning the heading of the takraw game are stated to have significant differences, these results can be seen in the Independent Samples Test table

Table 3. Service Takraw Learning T Tes

\begin{tabular}{lccccc}
\hline & Group Statistics & & \\
\hline Sepak Takraw Learning Techniques & $\mathrm{N}$ & Mean & $\begin{array}{c}\text { Std. } \\
\text { Deviation }\end{array}$ & $\begin{array}{c}\text { Std. Error } \\
\text { Mean }\end{array}$ \\
& & & & 6,92 & 1,26 \\
Sepak Takraw Learning & Pre-Test Service & 30 & 64,13 & 6,92 & 8,66 \\
Outcomes & Po-Test Service & 30 & 81,33 & 4,74 & \\
\hline
\end{tabular}




\begin{tabular}{|c|c|c|c|c|c|c|c|c|c|c|}
\hline \multirow[b]{4}{*}{$\begin{array}{l}\text { Sepak } \\
\text { Takra } \\
\text { w }\end{array}$} & \multirow{5}{*}{$\begin{array}{l}\text { Equal } \\
\text { variances } \\
\text { assumed } \\
\text { Equal } \\
\text { variances not } \\
\text { assumed }\end{array}$} & \multicolumn{2}{|c|}{$\begin{array}{l}\text { Levene's Test } \\
\text { for Equality } \\
\text { of Variances }\end{array}$} & \multicolumn{7}{|c|}{ t-test for Equality of Means } \\
\hline & & \multirow[t]{2}{*}{$\mathrm{F}$} & \multirow[t]{2}{*}{ Sig. } & \multirow[t]{2}{*}{$\mathrm{t}$} & \multirow[t]{2}{*}{ df } & \multirow{2}{*}{$\begin{array}{l}\text { Sig. } \\
(2- \\
\text { taile } \\
\text { d) } \\
\end{array}$} & \multirow[t]{2}{*}{$\begin{array}{c}\text { Mean } \\
\text { Differen } \\
\text { ce }\end{array}$} & \multirow{2}{*}{$\begin{array}{c}\text { Std. } \\
\text { Error } \\
\text { Differe } \\
\text { nce } \\
\end{array}$} & \multicolumn{2}{|c|}{$\begin{array}{l}\text { 95\% Confidence } \\
\text { Interval of the } \\
\text { Difference }\end{array}$} \\
\hline & & & & & & & & & Lower & Upper \\
\hline & & 4,99 & 0,29 & $-11,22$ & 58 & 0,00 & $-17,20$ & 1,53 & $-20,26$ & $-14,13$ \\
\hline $\begin{array}{l}\text { Learni } \\
\text { ng } \\
\text { Outco } \\
\text { mes }\end{array}$ & & & & $-11,22$ & 51,31 & 0,00 & $-17,20$ & 1,53 & $-20,27$ & $-14,12$ \\
\hline
\end{tabular}

Based on the table above, it can be concluded that the results of the pre-test and the post-test in learning the basic techniques of the servisof takraw have a significant value. Due to the value of Sig.(2-tailed) of $0.000<0.05$, then there is a significant difference between the scores on the pre-test and the po-test. Therefore, the results of the pre-test and po-test scores in learning the basic techniques of servis are stated to have significant differences, these results can be seen in the Independent Samples Test table.

Table 4. Smash Takraw Learning T Tes Tabel

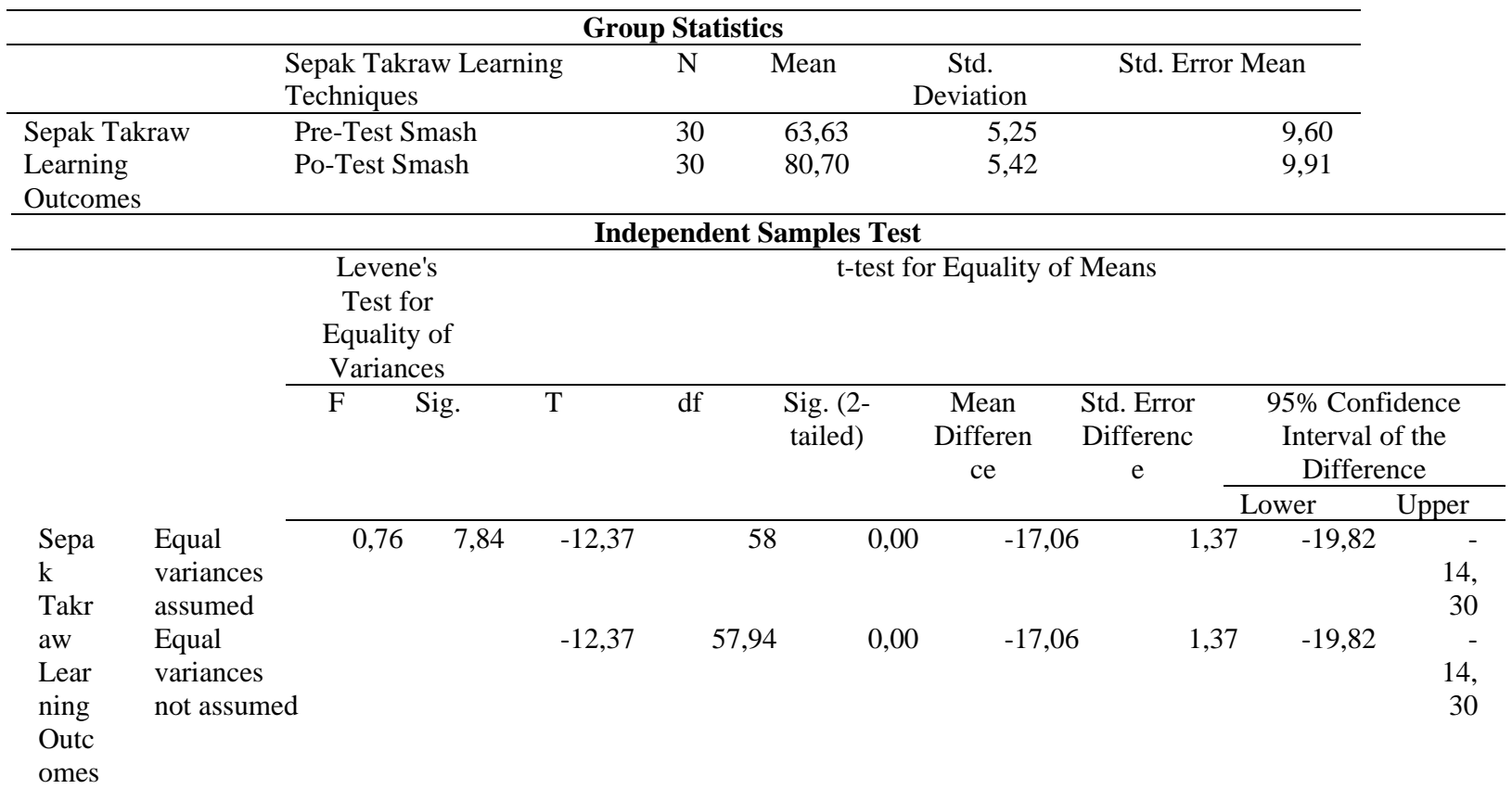

Based on the table above, it can be concluded that the results of the pre-test and the post-test in learning the basic techniques of smash takraw have a significant value. Due to the value of Sig.(2-tailed) of $0.000<0.05$, then there is a significant difference between the scores on the pre-test and the po-test. Therefore, the results of the pre-test and po-test scores in learning the basic techniques of smash are stated to have significant differences, these results can be seen in the Independent Samples Test table.

Based on the overall results of the t-test on learning basic takraw techniques, the results of the pre-tet and potest scores have a significant value. Because all the basic techniques of learning takraw starting from Silat, Heading, serving and smash have a Sig. (2-tailed) value of $0.000<0.05$, then there is a significant difference between the scores on the pre-test and the po-test on learning. basic technique of takraw game.

\section{CONCLUSION}

From the consequences of the information examination above, it very well may be reasoned that it is important to utilize Android application-based media innovation as an understudy concentrate on space to acquire rivalry the board capability without meeting up 
close and personal or lead match recreations in the field. The application that will be made is an android-based sepak takraw match scorer application that is upheld by video instructional exercises containing the utilization of the application, types of match rules and how to play sepak takraw.

\section{REFERENCES}

[1] Gunawan, I., \& Fardi, A. Pengaruh Variasi Latihan Sepak Sila Terhadap Ketepatan Operan Bola Dalam Sepak Takraw Pemain Sepak Takraw Putra SMP Negeri 17 Sijunjung. Jurnal Patriot, 2(1), 315327. 2020. DOI: 10.24036/patriot.v2i1.550.

[2] Alfiandi, P., Alidan N., Wardoy, H. Pengembangan Model Latihan SepakSila Pada Permainan Sepak Takraw, Jurnal Ilmiah Sport Coaching and Education, 2 (2), 2018. DOI : 10.21009/JSCE.02205.

[3] Purwanto, D. Development Of Playing Skills Sepak Takraw Exercises Models Based On Interactive Multimedia. Jipes - Journal Of Indonesian Physical Education And Sport, 3(1), 33 - 40. 2017. DOI: 10.21009/JIPES.031.05. 